\title{
Bank Credit, Trade Credit and Growth of Listed Agricultural Firms in Vietnam
}

\author{
Ninh Khuong LE ${ }^{1}$, Anh Tuan BUI ${ }^{2}$, Tu Anh PHAN ${ }^{3}$ \\ Received: August 01, 2020 Revised: September 20, 2020 Accepted: October 05, 2020
}

\begin{abstract}
This paper investigates the relationships between bank credit and trade credit with profit of 130 agricultural firms listed on Vietnam's stock exchanges during the period 2008-2014. Using the GMM approach, the paper reveals inverted-U shaped ( $\cap$ ) relationships between bank credit and trade credit with profit. Specifically, the optimal threshold of bank credit and trade credit to total assets of the firms are 0.4173 and 0.2425 , respectively. The findings mean that if the ratio of bank credit to total assets exceeds the benchmark of 0.4173 , firms should consider restructuring debts to get them back to the benchmark. To do so, firms should withdraw from those business fields that are not of their profession, in addition to liquiditizing unused assets to repay debts and not using short-term credit to invest in long-term projects. Firms may use trade credit wisely when other sources of finance are lacking. In concrete terms, firms can increase trade credit use if the ratio of trade credit to total assets is below 0.2425 . Yet, if this ratio goes beyond this benchmark, firms should get back to this benchmark, e.g., keeping a suitable amount of inventory. The implications of this study is to boost firm growth in the proposed way.
\end{abstract}

Keywords: Bank Credit, Growth, Listed Firm, Trade Credit, Vietnam

JEL Classification Code: P34, L25, G20

\section{Introduction}

Agricultural firms that produce, process, trade agricultural products or supply inputs to agricultural production have greatly contributed to the economic growth of Vietnam and created needed jobs for the people to make ends meet, especially those residing in the rural areas. Like other firms, agricultural firms in Vietnam use bank credit and trade credit to finance business activities as well as longterm investments, in addition to internal funds gradually accrued from retained earnings.

${ }^{1}$ First Author and Corresponding Author. Dean, Department of Economics, College of Economics, Can Tho University, Vietnam [Postal Address: 3/2 Street, Campus 2, Ninh Kieu District, Can Tho City, Can Tho Province, 900000, Vietnam] Email: Ikninh@ctu.edu.vn ${ }^{2}$ Deparment of Inspection, Can Tho City, Vietnam.

Email: buituananhct@gmail.com

${ }^{3}$ Chair, Department of International Business, College of Economics,

Can Tho University, Vietnam. Email: patu@ctu.edu.vn

(c) Copyright: The Author(s)

This is an Open Access article distributed under the terms of the Creative Commons Attribution Non-Commercial License (https://creativecommons.org/licenses/by-nc/4.0/) which permits unrestricted non-commercial use, distribution, and reproduction in any medium, provided the original work is properly cited.
Bank credit is crucial for firms because of three reasons. First, it enables firms to modernize technology so as to improve product quality for enlarging market share to sustain growth. Second, bank credit allows firms to repay due debts, thereby stabilizing operations to tackle difficulties stemming from market uncertainty and competition from rivals. Third, bank credit has an advantage of tax deduction (i.e., interest rate payments are exempted from tax) that helps accumulate capital for firms to take up profitable business opportunities, thus contributing to their growth prospect. Yet, not all firms are able to get access to bank credit as normally wished, due to low creditworthiness, information asymmetry, high transaction cost and credit crunch emerging in the difficult time for the banking system. In such a situation, firms have to resort to trade credit in the form of deferred payments to input purchase (i.e., accounts payable). Thanks to its convenience, trade credit turns out to be important for firms to exploit business opportunities, thereby becoming more efficient and growing as fast as possible (Nguyen and Lien, 2019).

Most studies - both theoretical and empirical - have strongly emphasized the key role of bank credit and trade credit for firm growth. Yet, the dependence on bank credit and trade credit may challenge the possibility of growth 
for the firms. In fact, when interest rates somehow rises, the obligation to repay debts becomes too heavy (even prohibited) because of increased user costs of capital. As a consequence, firms have to scale down their operations or or even go bankrupt. This means that any overuse of bank credit may have a detrimental impact on the growth of the firms . Trade credit also has an identical impact, especially if not knowing the exact purpose of trade creditors, firms may be unable to properly respond to the changes in policy made by them. Moreover, the interrelatedness between bank credit and trade credit (i.e., substitute or complement) may also alter firm growth in certain circumstances. The aforementioned arguments mean that using bank credit and trade credit wisely is the key to sustainable growth for firms. However, those issues have not got sufficient attention from researchers in Vietnam so as to help firms make optimal use of those precious resources and use funds more efficiently for continouus growth.

Given that concern, this research paper has been conducted to empirically investigate the impact of bank credit and trade credit on firm growth, using a panel data set of 130 Vietnamese listed agricultural firms during the period of 2008-2014 and estimate optimal ratios of bank credit and trade credit to total assets in order to sustain the fastest growth rate of sales for those firms. This paper is structured as follows. Section 1 introduces the paper. Section 2 reviews the related literature. Section 3 specifies the empirical model out of the literature reviewed. Section 4 is about the data set and the estimation strategy. Section 5 describes the sample. Section 6 analyzes the findings. Section 7 concludes and then comes up with policy recommendations.

\section{Literature Review}

\subsection{Bank Credit and Firm Growth}

Bank credit is a pivotal source of funds for firms to maintain and develop business. Given the diversity of loan terms, bank credit enriches both working and fixed capital, thereby ensuring the continuity and expansion of firm operations. Several studies have applied the MM propositions developed by Modigliani and Miller (1958), Modigliani and Miller (1963) to confirm the advantage of bank credit, since interest rate payments are exempted from tax. Firms can use the deducted tax to finance investments to boost production and growth.

Bank credit can also be used to invest in research and development (R\&D) activity to upgrade technology, thus enhancing competitiveness and rendering a solid platform for firms to sustain growth. As a matter of fact, updated technology helps firms improve product quality, push up productivity and mitigate production costs. Firms that are denied access to credit often rely on backward technology, so both product quality and productivity are low. As a result, market share and growth opportunities will vanish eventually. Studies have also identified the key role of bank credit in financing exports - an important source of growth for firms operating in saturate domestic markets (Abor et al., 2014). To access foreign markets, firms incur costs of searching, developing and maintaining distribution systems, in addition to commodity insurance and taxes. Most of those costs must be committed prior to getting paid for exported goods, so firms need to be financed in advance. Since the transportation of exported goods to foreign destinations are basically expensive compared to domestic ones, firms may find themselves in short of internal funds and have to rely on external ones. Thus, firm exports and growth largely depends on bank credit (Minetti and Zhu, 2010; Le and Kim, 2020).

As just argued, bank credit plays an active role in firm growth. However, any misuse of this source of funds will bring in detrimental effects to firms, as confirmed by a number of studies (e.g., Jiao, 2010; Nkurunziza, 2011). Jiao (2010) develops a model to reveal the inverted-U shaped $(\cap)$ relation between bank credit and firm growth. According to Nkurunziza (2011), when the economy is stuck with hardships, interest rates somehow rise, firms must shoulder heavy burdens of repaying debt, especially if having borrowed too much. As a consequence, firms have to scale down, limit investment or go bankrupt eventually.

The fact that firms are so driven by the profitability factor in the past that they borrow too much to invest in scale and scope expansions regardless of output market uncertainty also explains why bank credit adversely affects firm growth (Le and Huynh, 2014). In fact, as output markets decline, it is hard for firms to repay a substantial amount of bank debt due to difficulties in fetching external and internal funds for that purpose (e.g., in the time of credit crunch). Nguyen and Trang (2013) observe harmful effects of bank credit on firm growth and asserts that slow growing firms often use less bank credit to finance activities and investments, as opposed to fast growing ones.

\subsection{Trade Credit and Firm Growth}

The impact of trade credit on firm growth has been a matter of concern for researchers for long, since this is a very common financing source for firms. Most researchers have agreed that if used properly trade credit will spur firm growth and vice versa (Kwon et al., 2020). According to Schwartz and Witcomb (1979), trade credit plays a key role in funding activities of firms via the means of deferred payments (i.e., accounts payable), since trade credit beneficiaries are not obliged to pay for the purchased goods right away. Therefore, trade credit enables firms to accumulate funds to take up promising opportunities for higher growth. 
According to Schwartz (1974), when the government limits credit growth to curb inflation, several firms will face difficulty in getting access to bank credit, except for those with a strong financial stand. Firms that are eligible for bank loans will grant trade credit to those that are not in order to assist the latter in developing production and stimulating growth. Ferris (1981) points out the positive impact of trade credit on firm growth via the channel of minimizing transaction cost, especially with regard to input purchase. In fact, commodity transactions are involved with transaction costs that dampen the possibility for the growth of the firms. Thus, the lag between the time of receiving the goods and that of repaying for it (i.e., deferred payments) enables firms to mitigate transaction cost and the risk of holding cash, thereby creating good opportunities for firms to grow (Petersen and Rajan, 1997).

According to Burkart and Ellingsen (2004), trade credit also helps firms grow since they tend to use the input purchased using trade credit in production instead of diverting it for a couple of reasons. First, trade creditors have a better position to supervise the behaviour of trade credit beneficiaries and will impose an outright sanction if the latter diverts the purchased input, which adversely affects the possibility to repay loans. This threat is strongly effective, especially for those firms facing difficulty in getting access to other external sources of funds. Second, Brennan et al. (1988) argues that trade credit functions as a price differentiation device for firms to maximize profit. Therefore, several firms provide trade credit, especially those operating in fiercely competitive markets (Petersen and Rajan, 1997). This policy benefits trade credit receivers since they can flexibly select the deferred payment term that best suits the aim of promoting growth. Third, several firms (e.g., new ones that have started from scratch) use trade credit to compete against rivals (Fisman and Raturi, 2004). Being new market players, as their products have not gained sufficiently impressive brand image to allure customers, they resort to trade credit to mitigate competitive pressure (e.g., that from experienced rivals with immense market powers) and the risk of failing. Trade credit with generous terms enables its receivers to make good strategies to use funds for pursuing promising growth opportunities. Finally, several studies pay attention to the function of trade credit as a marketing device to build up prestiges and sustain their relations with the customers, thus enlarging market share (Summers and Wilson, 2002). Putting it differently, providing trade credit will mitigate the problem of information asymmetry on product quality for trade credit receivers, thereby creating and ensuring their trust (Cheng and Pike, 2003). Given this attribute, trade credit is widely deemed to be an effective marketing device to stimulate demand and bring about growth opportunities for trade credit beneficiaries.
However, trade credit has a dark side stemming from hidden risks that hinder firm growth. In fact, trade credit implicitly contains risks since trade creditors may change their policy of providing trade credit (especially as having got enough market power), thus unexpectedly asking customers (i.e., trade credit receivers) to repay all the loans previously given or totally stop trade credit grants later on. This policy may not be harmful for firms that use trade credit with a proper amount but may have an increasingly bad impact on those depending too much on this specific type of credit. As a result, trade credit will adversely affect growth of the firms. The aforementioned arguments imply an inverted-U shaped $(\cap)$ relation between trade credit and firm growth. Differently stating, if trade credit picks up from a minor level, firms will grow faster. Yet, if going beyond a certain limit, trade credit will gradually curtail firm growth.

\subsection{Joint Impact of Bank Credit and Trade Credit on Firm Growth}

Studies have often treated the impacts of bank credit and trade credit on firm growth separately. However, these two types of credit may interplay to influence firm growth since they are somehow interrelated (i.e., substitute or complement). Thus, it is wise to consider their joint impact on firm growth.

\subsubsection{Substitute}

One strand of the literature on finance focusing on the relation between bank credit and trade credit argues that firms (e.g., those having short-lived relations with banks) rely on trade credit when facing difficulty in getting access to bank loans, since banks may not offer them sufficient credit due to information asymmetry, transaction cost, limited liability and credit crunch (Danielson and Scott, 2004). Besides, during financial crises that make information about firms even more opaque than usual, banks tend to ration credit and then trade credit becomes a more needed means of finance for firms. In that case, trade credit acts as a substitute for bank credit (Burkart and Ellingsen 2004; Psillaki, 2015). A number of empirical studies have examined the relation between bank credit and the behaviour of trade credit during financial crises. For instance, Mateut et al. (2006) find that firms are inclined to use trade credit as a substitute for bank credit under monetary contractions as a prudent policy mandated by the central bank to contain adverse effects of financial crises.

In countries where financial systems are less developed, commercial banks often lend carelessly and inappropriately for a prolonged period. In the course of time, the loans turn sour and the full extent of bad debts emerges. To tackle the problem, commercial banks suddenly reduce the 
availability of loans or tighten the conditions required to obtain loans (i.e., credit crunch), as adverse information about the financial soundness of borrowers and the dropped value of collateral becomes more prevalent. Credit crunch is often accompanied by a flight to quality by lenders as they seek less risky investments (usually at the expense of small to medium size enterprises). In such a situation, many firms have to switch to trade credit so as to circumvent fund shortage that is very harmful to their production and growth (Ge and Qiu, 2007). Firms that have good relations with trade creditors may enjoy low cost of this type of credit, therefore being more eager to substitute bank loans for trade credit. Similarly, for those firms having a strong capital base, bank credit and trade credit are also substitutes since they tend to select only one out of the two that best conforms to their own growth target (Burkart and Ellingsen 2004)

If bank credit and trade credit are substitutes, their joint impact on firm growth is basically indeterministic since one is offset by the other. In fact, that impact depends on the relative costs of those credit sources, but it is seemingly impossible to ascertain which one is more expensive. Therefore, the joint impact of bank credit and trade credit on firm growth can only be proved by empirical investigations rather than theoretical reasonings.

\subsubsection{Complement}

Researchers argue that the relation between accounts payable and bank loan availability is positive since firms increase trade credit use as bank loan availability improves (Tsuruta, 2015). Differently stating, accounts payable and bank loans are virtually complementary for firms. Moreover, studies assert that thanks to intimate relations with customers, suppliers have information advantage over banks such that lending decisions of banks are determined by the availability of trade credit to firms (Aktas et al., 2012). In concrete terms, since trade creditors are more effective at monitoring and enforcing contracts, it may be better for banks to lend to those firms that have been given trade credit.

This complementary hypothesis expects that trade credit to be positively related to bank credit. Burkart and Ellingsen (2004) divulges that trade credit may alter the amount of bank credit firms can obtain, since increased trade credit enables firms to conduct better investments to become more successful, thereby inducing banks to grant more credit for firms to grow faster. Atanasova (2012) finds that trade credit has a positive impact on bank loans for firms with high agency costs due to information asymmetry, supporting the signaling role of trade credit provision to lending decisions of banks.

In short, the interplay between bank credit and trade credit may have a certain impact on firm growth but it is indeterministic on which sign (i.e., positive or negative) that this impact may take, meaning that an empirical examination is of much need.

\section{Empirical Model}

Based on the theoretical background just discussed, we specify the following empirical model to detect the impact of bank credit and trade credit on the growth of listed agricultural firms in Vietnam as follows:

$$
\begin{aligned}
\text { GROWTH }_{i t}= & \beta_{0}+\beta_{1} \text { BANKCREDIT }_{i t}+\beta_{2} \text { BANKCREDIT }_{i t}^{2} \\
& +\beta_{3} \text { TRADECREDIT }_{i t}+\beta_{4} \text { TRADECREDIT }_{i t}^{2} \\
& +\beta_{5} \text { BANKCREDIT } \times \text { TRADECREDIT } \\
i t & +\varepsilon_{i t}(1)
\end{aligned}
$$

In Model (1), GROWTH ${ }_{i t}$ is annual growth rate of sales of firm $i$ in year $t(\%)$. In principle, firm growth can be measured using sales, total assets or the number of permanent labours (Wilson and Morris, 2000). As a matter of fact, most studies use sales since this criterion is a product of assets and labours of firms (Bertin and Warleta, 2012; Sola et al., 2013; Ferrando and Mulier, 2013).

$B A N K C R E D I T_{i t}$ is the ratio of bank credit to total assets of firm $i$ in year $t$. BANKCREDIT $T_{i t}^{2}$ (squares of BANKCREDIT ) is used to test for the presence of an inverted-U shaped $(\cap)$ relation between bank credit and the growth rate of sales of firms, as explained in the literature review. Coefficient $\beta_{1}$ is supposed to be positive and $\beta_{2}$ to be negative due to such a specific relation $(\cap)$ between bank credit and firm growth. TRADECREDIT $T_{i t}$ is the ratio of accounts payable to total assets of firm $i$ in year $t$ and TRADECREDIT $T_{i t}^{2}$ is squares of TRADECREDIT $T_{i t}$, used to confirm the inverted U-shaped $(\cap)$ relation between trade credit and firm growth. Moreover, in order to reveal the joint impact of bank credit and trade credit on the growth rate of sales of firms, Model 1 includes the variable $B A N K C R E D I T_{i t} \times T R A D E C R E D I T_{i t}$ (i.e., interaction of bank credit and trade credit).

However, according to studies (Griliches, 1983; Rajan and Zingales, 1997; Gregory et al., 2005; Nicholson and Snyder, 2008; Ferrando and Mulier, 2013; Yazdanfar and Ohman, 2015), there are other determinants of firm growth. Thus, it is needed to augment Model (1) with those determinants that reads:

$$
\begin{aligned}
\text { GROWTH }_{i t}= & \beta_{0}+\beta_{1} \text { BANKCREDIT }_{i t}+\beta_{2} \text { BANKCREDIT }_{i t}^{2} \\
& +\beta_{3} \text { TRADECREDIT }_{i t}+\beta_{4} \text { TRADECREDIT }_{i t}^{2} \\
& +\beta_{5} \text { BANKCREDIT } \times \text { TRADECREDIT }_{i t} \\
& +\beta_{6} \text { EQUITY }_{i(t-1)}+\beta_{7} \text { TANGIBLE }_{i t}+\beta_{8} \text { FAGE }_{i t} \\
& +\beta_{9} \text { LABOUR }_{i t}+\beta_{10} \text { CASHFLOW }_{i t} \\
& +\beta_{11} \text { GROWTH }_{i(t-1)}+\beta_{12} \text { PRODUCTION }_{i t}+\varepsilon_{i t}
\end{aligned}
$$


In Model (2), EQUITY $i_{i(t-1)}$ is logarithm of equity of firm $i$ in year $t-1$. In countries with less developed financial systems, information asymmetry prevails and transaction cost is high, equity that has a valuable advantage of lower user cost turns out to be a prominent source of funds for firms, before contemplating external ones (Yazdanfar and Ohman, 2015). Since equity of the previous year would be used to meet the need in the present year, larger time-lagged equity enables firms to obtain higher growth rates if used properly to embark on promising growth opportunities. Yet, in some cases firms misuse equity, thus resulting in losses and hindering growth, especially when the economy is on the verge of recession and faces stringent harshness. Therefore, coefficient $\beta_{6}$ may have either positive or negative signs.

TANGIBLE $E_{i t}$ is the ratio of tangible assets to total assets of firm $i$ in year $t$. Being used as collateral for acquiring external funds, tangible assets allow firms to obtain credit as easily and quickly as wished, since most credit institutions in Vietnam follow the collateral-based lending approach. Differently speaking, firms with tangible assets of higher value will find themselves in much easier positions to get funded with external sources so as not to miss promising growth opportunities (Rajan and Zingales, 1997; Chen and Chen, 2011). Thus, coefficient $\beta_{7}$ is supposed to be positive.

$F A G E_{i t}$ (i.e., firm age) is the number of years in operation of firm $i$ up to year $t$. Age is an almost perfect proxy for experience - a factor that positively affects firm growth as identified by Rahaman (2011), among others. Thus, coefficient $\beta_{8}$ is expected to be positive. However, firms operating in saturated environments would become conservative and allergic to changes and thus have low growth rates, especially those doing business in the agricultural sphere in developing and less developed countries (Gregory et al., 2005). This would mean that coefficient ${ }_{8}$ is negative. That which effect dominates can only be better tested using empirical data instead of merely theoretical reasonings.

$L A B O U R_{i t}$ is total number of permanent labours of firm $i$ in year $t$. As just mentioned, the number of permanent labours is a proxy for firm size, next to fixed assets and sales. The theory on economy of scale argues that, to some extent, larger firms have advantages over smaller ones, since long-term average cost of production tends to drop as output accrues (Nicholson and Snyder, 2008). Given this, large firms may lower prices to allure customers and increase market share, thereby growing faster (Ferrando and Mulier, 2013). Thus, coefficient $\beta_{9}$ should be positive.

CASHFLOW ${ }_{i t}$ is the ratio of operational cash flows to total assets of firm $i$ in year $t$. To some extent, cash flows convey information on financial capacity of firms. If cash flows are in shortage, then there is an existance of increased threats that emanate bad signals about financial soundness and growth prospects of firms. Firms can only survive if cash flows are mainly created from business activities and if thet are able to meet their own needs (Nguyen and Tu, 2015). If having sufficiently surplus cash flows, firms will be able to utilize good investment opportunities because, according to the pecking-order theory, internal funds should be the first choice for firm financing (Nguyen and Trang, 2013). Otherwise, firms will face liquidity harshness, thereby being unable to maintain relations with partners (i.e., financiers, suppliers and customers). This implies that cash flows may have positive impact on firm growth and coefficient $\beta_{10}$ is thus positive.

Table 1: Expected sign of coefficients in Model (2)

\begin{tabular}{|c|c|c|}
\hline Variables & Meanings & Expected sign of $\boldsymbol{\beta}_{j}$ \\
\hline BANKCREDIT & Ratio of bank credit to total assets & Positive \\
\hline$B A N K C R E D I T_{i t}^{2}$ & Squares of $B A N K C R E D I T_{i t}$ & Negative \\
\hline TRADECREDIT $_{\text {it }}$ & Ratio of accounts payable to total assets & Positive \\
\hline TRADECREDIT ${ }_{i t}^{2}$ & Squares of TRADECREDIT & Negative \\
\hline $\begin{array}{l}\text { BANKCREDIT }{ }_{i t} \\
\text { TRADECREDIT }_{i t}\end{array}$ & Bank credit multiplied by trade credit & Positive/Negative \\
\hline$E Q U I T Y_{i(t-1)}$ & Logarithm of equity in the previous year & Positive/Negative \\
\hline TANGIBLE $_{i t}$ & Ratio of tangible assets to total assets & Positive \\
\hline$F A G E_{i t}$ & Number of years in operation & Positive \\
\hline LABOUR $_{i t}$ & Number of permanent labours & Positive \\
\hline CASHFLOW $_{i t}$ & Ratio of operational cash flow to total assets & Positive \\
\hline GROWTH $_{i(t-1)}$ & Annual growth rate of sales in the previous year $(\%)$ & Positive/Negative \\
\hline PRODUCTION $_{i t}$ & $\begin{array}{l}\text { Being } 1 \text { for firms participating in production, processing and trading } \\
\text { agricultural products and } 0 \text { for the others }\end{array}$ & Positive/Negative \\
\hline
\end{tabular}


$\mathrm{GROWTH}_{i(t-1)}$ (i.e., annual growth rate of sales of firm $i$ in year $t-1)$ is included in the empirical model to test for the relation between the growth rate of sales in the previous year and that in the present year. According to Rahaman (2011), growth of a firm in certain years is related to that in the previous year since the latter conveys information about the possibility to grow in the coming years. This information creates incentive to invest to stimulate growth if future opportunities are promising and vice versa. Therefore, growth in year $t$ is connected with that in year $t$ -1 . In other words, coefficient $\beta_{11}$ may be of either positive or negative sign, according to the status quo of firms under consideration.

PRODUCTION $_{i t}$ takes a value of 1 for firms that produce, process or trade agricultural products and 0 for those supplying inputs to agricultural production. Coefficient $\beta_{12}$ may be positive or negative. $\varepsilon_{i t}$ is the random error of the model. Meanings and expected sign of coefficients $\beta$. $(j=\overline{1,12})$ are shown in Table 1 based on the theoretical reasonings previously presented (See Table 1).

\section{Data and Estimation Strategy}

In order to test for the impact of bank credit and trade credit on firm growth, we use a panel data set retrieved from audited financial statements of 130 Vietnamese agricultural firms listed on Ho Chi Minh City Stock Exchange (HOSE) and HaNoi Stock Exhange (HNX) in the period of 20082014. Strength of this data set lies in its accuracy and reliability that enable us to draw precise conclusions and propose pragmatic recommendations for firms to take up.

We use descriptive statistics to describe the status quo of the firms that underpins the explanation of the estimation results. In order to estimate the impact of bank credit and trade credit on growth rate of sales of the firms, we first try random effect (RE) and fixed effect (FE) estimation methods. As a matter of fact, firms use bank credit and trade credit to boost growth so as to enlarge size and market share. Then, inspired by high growth rates firms tend to use more bank credit and trade credit since it is more plausible for them to get access to those sources of finance. Differently stating, there exist causal effects between bank credit and trade credit with the growth rate of sales of firms. As a result, BANKCREDIT $T_{i t}$ and TRADECREDIT ${ }_{i t}$ are correlated with the model's error, thus rendering the problem of endogeneity in the empirical model (Angrist and Krueger, 2001; Rahaman, 2011). The problem of endogeneity will make the results estimated by RE and FE methods virtually biased and unreliable (Tran and Do, 2015).

In order to tackle the problem of endogeneity, it is surely better to use the Generalized Method of Moments (GMM) developed by Arellano and Bond (1991) and widely applied by many empirical studies (see below) to estimate Model
(2) in order to make the estimation result unbiased and more statistically reliable as well, especially in the case of panel data. This estimation method requires instrumental variables for the two endogenous variables (i.e., BANKCREDIT $T_{i t}$ and $T R A D E C R E D I T_{i t}$ ). In this case, we use time-lagged (one year) variables as instruments for the two endogenous variables as often done by a number of studies that have utilized GMM approach (e.g., Rahaman, 2011; Bertin and Warleta, 2012; Sola et al., 2013).

\section{Overview of the Surveyed Firms}

Annual growth rate of sales of the surveyed firms is $14.32 \%$ with a standard deviation of $36.27 \%$, divulging the gap in the growth rate of sales of those firms. This gap stems from output market uncertainty, managerial incompetence as well as inefficient use of funds (e.g., bank credit and trade credit). In the period 2008-2014, the firms tried to expand to make use of business opportunities, so sales increased and more labour was hired, but at decreasing growth rates because of difficulties resulting from competition by foreign rivals and suppressed demands for their products (Table 2). This tendency seems to cause a remarkable drop in profits of the firms, due to incompetent management and unfavourable market conditions resulting from the lingering economic and financial crises.

Since 2008, several segments of the corporate sector have exhibited poor performance and financial distress precipitated by macroeconomic instability, thus affecting the health of the banking system. A number of state-owned enterprises (SOEs) defaulted on their debt obligations and many others appeared to be overleveraged. The banking system accumulated a significant amount of non-performing loans (NPLs), estimated at 12 percent of total outstanding loans at the end of 2012 (World Bank, 2014). Small banks experienced serious liquidity and solvency problems, inviting prompt interventions by the State Bank to improve credit decisions of commercial banks, curtail connected lending by joint-stock banks and cure the weaknesses in financial infrastructure, in addition to enhancing financial reporting standards and deficiencies in financial regulation and supervision (World Bank, 2014). Increased macroeconomic volatility in the period of 2008-2014 intensified the problem and led to further deterioration in the quality of loan portfolios (See Table 2).

As a result, credit growth slowed down due to concerns over non-performing loans, resulting in a credit crunch. This fact is adversely coupled with the contractionary monetary policy imposed by the Government to contain inflation. In such a circumstance, firms were inclined to resort to trade credit in terms of deferred payments to input purchase as an alternative, pushing the type of credit in 2014 up to approximately three times of that in 2008 (Table 2). 
Table 2: Fundamental indicators of the surveyed firms (2008-2014)

\begin{tabular}{|c|c|c|c|c|c|c|c|}
\hline Indicators & 2008 & 2009 & 2010 & 2011 & 2012 & 2013 & 2014 \\
\hline Sales (VND trillion) & $\begin{array}{c}818 \\
-\end{array}$ & $\begin{array}{c}911 \\
(11.4)\end{array}$ & $\begin{array}{c}1.086 \\
(19.2)\end{array}$ & $\begin{array}{l}1.379 \\
(27.0)\end{array}$ & $\begin{array}{l}1.475 \\
(7.0)\end{array}$ & $\begin{array}{c}1.594 \\
(8.1)\end{array}$ & $\begin{array}{l}1.698 \\
(6.5)\end{array}$ \\
\hline Labours (1,000 people) & $\begin{array}{c}1,030 \\
-\end{array}$ & $\begin{array}{c}1,080 \\
(4.8)\end{array}$ & $\begin{array}{l}1,119 \\
(3.6)\end{array}$ & $\begin{array}{c}1,173 \\
(4.8)\end{array}$ & $\begin{array}{c}1,253 \\
(6.1)\end{array}$ & $\begin{array}{c}1,319 \\
(5.9)\end{array}$ & $\begin{array}{c}1,343 \\
(1.3)\end{array}$ \\
\hline Profit (VND trillion) & $\begin{array}{l}50 \\
-\end{array}$ & $\begin{array}{c}84 \\
(68.0)\end{array}$ & $\begin{array}{c}120 \\
(42.9)\end{array}$ & $\begin{array}{c}131 \\
(9.2)\end{array}$ & $\begin{array}{c}118 \\
(-9.9)\end{array}$ & $\begin{array}{c}124 \\
(5.1)\end{array}$ & $\begin{array}{c}127 \\
(2.4)\end{array}$ \\
\hline Total assets (VND trillion) & $\begin{array}{c}627 \\
-\end{array}$ & $\begin{array}{c}764 \\
(21.9)\end{array}$ & $\begin{array}{c}961 \\
(25.8)\end{array}$ & $\begin{array}{l}1,197 \\
(24.6)\end{array}$ & $\begin{array}{l}1,352 \\
(12.9)\end{array}$ & $\begin{array}{c}1,485 \\
(9.8)\end{array}$ & $\begin{array}{l}1,663 \\
(12.0)\end{array}$ \\
\hline Bank credit (VND trillion) & $\begin{array}{c}157 \\
-\end{array}$ & $\begin{array}{c}189 \\
(20.4)\end{array}$ & $\begin{array}{c}228 \\
(20.6)\end{array}$ & $\begin{array}{c}286 \\
(25.4)\end{array}$ & $\begin{array}{c}318 \\
(11.2)\end{array}$ & $\begin{array}{c}347 \\
(9.1)\end{array}$ & $\begin{array}{c}380 \\
(9.5)\end{array}$ \\
\hline Accounts payable (VND trillion) & $\begin{array}{c}52 \\
-\end{array}$ & $\begin{array}{c}62 \\
(19.2)\end{array}$ & $\begin{array}{c}77 \\
(24.2)\end{array}$ & $\begin{array}{c}103 \\
(33.8)\end{array}$ & $\begin{array}{c}113 \\
(9.7)\end{array}$ & $\begin{array}{c}132 \\
(16.8)\end{array}$ & $\begin{array}{c}141 \\
(6.8)\end{array}$ \\
\hline
\end{tabular}

Source: Calculated from audited financial statements of the firms. Note: Figures in brackets are annual change (\%).

\section{Estimation Results}

The estimation results for the test of the impact of bank credit and trade credit on the growth rate of sales of the firm are shown in Table 4. Columns 2, 3, and 4 of this table present the results of RE, FE, and GMM estimation methods, respectively. Despite being unable to tackle the problem of endogeneity, since RE and FE are common estimation methods for time-series data, we present their results as reference.

Prior to conducting the regression of Model (2) using the GMM method, we perform a check for multi correlation between the independent variables that are described in Table 3. The result shows that all the coefficients between the independent variables are much smaller than 0.8 , implying no multi correlation problem in the empirical model (Bertin and Warleta, 2012; Yazdanfar, 2012; Sola et al., 2013; Yazdanfar and Ohman, 2015). We have also been concerned with the problem of heteroscedasticity, but this problem is automatically corrected by the GMM method itself (Cragg, 1983; Wooldridge, 2001; Ho, 2014). The Sargan test shown in column 4 confirms the robustness of the instrumental variables as exogenous variables (i.e., having no correlation with the model's error). Moreover, Wald test rejects $\mathrm{H}_{0}$ hypothesis (i.e., all coefficients of the independent variables being equal to zero). Differently speaking, all the coefficients of the independent variables of Model 2 have explanatory powers (See Table 3 ).
GMM estimation method shows that BANKCREDIT has coefficient $\beta_{1}=3.9281$ and BANKCREDIT $T_{i t}^{2}$ has coefficient $\beta_{2}=-4.5323$ at significance levels of $5 \%$ and $1 \%$, respectively. This result confirms the inverted- $U$ shaped $(\cap)$ relation between bank credit and the growth rate of sales of the firms as pointed out in Section 2. Given the fact that $\beta_{5}$ of variable BANKCREDIT $_{\text {it }} \times$ TRADECREDIT $_{i}$ is not statistically significant, taking partial derivative of GROWTH $_{\text {it }}$ of Model (2) with respect to BANKCREDIT gives:

$$
\frac{\partial \text { GROWTH }_{i t}}{\partial B A N K C R E D I T_{i t}}=\beta_{1}+2 \beta_{2} \text { BANKCREDIT }_{i t}
$$

Then, it is plausible to identify the optimal ratio of bank credit to total assets corresponding to the highest growth rate of sales of the firms that satisfies

$$
\begin{aligned}
\beta_{1}+2 \beta_{2} \text { BANKCREDIT }_{i t} & =0 \text { or } \text { BANKCREDIT }_{i t} \\
& =-\beta_{1} / 2 \beta_{2}
\end{aligned}
$$

The value of $\beta_{1}, \beta_{2}$ given in Table 3 and expression (4) allow us to come up with $B A N K C R E D I T_{i t}=0.4334$. Note: Given this ratio and total assets, we can measure the amount of bank credit that each firm should use to get sales to grow fastest. Differently speaking, if the ratio of bank credit to total assets is below 0.4334 , an increase in bank credit pushes up the growth rate of sales of the firms and vice versa, for the reasons clarified in the literature review. 
Table 3: Statistical summary of the independent variables

\begin{tabular}{|c|c|c|c|c|c|}
\hline Variables & Mean & Median & Max & Min & S.D. \\
\hline$B A N K C R E D I T_{i t}$ & 0.284 & 0.258 & 1.048 & 0.000 & 0.234 \\
\hline$B A N K C R E D I T_{i t}^{2}$ & 0.137 & 0.066 & 1.379 & 0.000 & 0.171 \\
\hline TRADECREDIT $T_{i t}$ & 0.075 & 0.055 & 0.610 & 0.000 & 0.071 \\
\hline TRADECREDIT ${ }_{i t}^{2}$ & 0.017 & 0.003 & 0.654 & 0.000 & 0.057 \\
\hline $\begin{array}{l}\text { BANKCREDIT } \\
\text { TRADECREDIT }_{i t}\end{array}$ & 0.023 & 0.011 & 0.421 & 0.000 & 0.031 \\
\hline$E Q U I T Y_{i(t-1)}$ & 0.522 & 0.518 & 7.968 & -0.478 & 0.340 \\
\hline TANGIBLE $_{i t}$ & 0.313 & 0.299 & 0.986 & 0.033 & 0.153 \\
\hline$F A G E_{i t}$ & 24.385 & 22.000 & 62.000 & 2.000 & 12.701 \\
\hline$L^{\prime A B O U R_{i t}}$ & $1,186.870$ & 579.500 & 24.111 & 22.000 & $1,992.050$ \\
\hline CASHFLOW $_{i t}$ & -0.025 & 0.003 & 1.987 & -28.537 & 0.965 \\
\hline PRODUCTION & 0.612 & 1.000 & 1.000 & 0.000 & 0.487 \\
\hline
\end{tabular}

Source: Calculated from audited financial statements of the firms.

TRADECREDIT $_{i t}$ has coefficient $\beta_{3}=10.8168$ and $T R A D E C R E D I T_{i t}^{2}$ has coefficient $\beta_{3}=-28.0484$ at the same significance level of $1 \%$. This outcome also confirms the inverted-U shaped $(\cap)$ relation between trade credit and the growth rate of sales of the firms. Using a similar approach to bank credit, we can estimate the optimal ratio of trade credit to total assets of the firms of approximately 0.1928 . This means that if the ratio of trade credit to total assets is below 0.1928 , trade credit will boost the growth rate of sales of the firms and the effect reverses if the ratio goes beyond that benchmark.

It is interesting that $\beta_{3}>\beta_{1}$, implying the more important role of trade credit to firm growth as compared with bank credit, other things being equal. This finding is quite understandable, since during the period of financial distress banks had used contracted lending policies (especially to those firms that are financially unsound) while the government curtailed the growth rate of credit given to the economy. In other words, this is an advocate of the reality of credit crunch emerging as a consequence of prudent policies maintained by banks and the Government.
Given $\beta_{6}=-1.6090$ of variable EQUITY $Y_{i(t-1)}$ The estimation result reveals a negative impact of equity in the previous year on the growth rate of sales in the present year because a number of firms have inefficiently used this internal source of funds, e.g. to invest in nonprofessional fields of specialization (such as real estate). Coefficient $\beta_{11}$ of variable $\mathrm{GROWTH}_{i(t-1)}$ is negative at a significance level of $1 \%$, pointing out an unstable growth of the firms, due to output market uncertainty and fierce competition from rivals. Following Vietnam's accession to membership in the World Trade Organization (WTO) in 2007, booming foreign capital inflows spurred a surge in domestic credit growth, a sharp rise in inflation and boom in real estate and stock markets. All this in fact confronted Vietnam with severe macroeconomic instability, consisting of continued high inflation, high interests rates, large trade deficit and rising public debt, which advocately explains the unstable growth facing the firms under consideration. Coefficients of the remaining independent variables are statistically insignificant (Table 4). 
Table 4: Estimation results by the methods of FE, RE, and GMM

Dependent variable: GROWTH ${ }_{i t}$ - Annual growth rate of sales of the firm (\%)

\begin{tabular}{|c|c|c|c|}
\hline Variables & RE & FE & GMM \\
\hline (1) & (2) & (3) & (4) \\
\hline$B$ ANKCREDIT & $\begin{array}{l}0.2857^{*} \\
(0.0857)\end{array}$ & $\begin{array}{c}0.2833 \\
(0.3115)\end{array}$ & $\begin{array}{l}3.9281^{* *} \\
(0.0204)\end{array}$ \\
\hline BANKCREDIT' ${ }_{i t}^{2}$ & $\begin{array}{c}-0.8421^{* * *} \\
(0.0002)\end{array}$ & $\begin{array}{c}-0.6499^{*} \\
(0.0662)\end{array}$ & $\begin{array}{c}-4.5323^{* * *} \\
(0.0027)\end{array}$ \\
\hline TRADECREDIT $_{i t}$ & $\begin{array}{l}1.3223^{* * *} \\
(0.0033)\end{array}$ & $\begin{array}{l}1.5781^{* *} \\
(0.0433)\end{array}$ & $\begin{array}{c}10.8168^{* * *} \\
(0.0053)\end{array}$ \\
\hline$T_{R A D E C R E D I T^{2}}^{2}$ & $\begin{array}{l}-2.9994^{*} \\
(0.0609)\end{array}$ & $\begin{array}{l}-3.8407 \\
(0.1531)\end{array}$ & $\begin{array}{c}-28.0484^{* * *} \\
(0.0014)\end{array}$ \\
\hline $\begin{array}{l}\text { BANKCREDIT } \times \\
\text { TRADECREDIT }_{i t}\end{array}$ & $\begin{array}{c}0.0951 \\
(0.6764)\end{array}$ & $\begin{array}{l}-0.2469 \\
(0.4283)\end{array}$ & $\begin{array}{l}-2.7158 \\
(0.3827)\end{array}$ \\
\hline$E Q U I T Y_{i(t-1)}$ & $\begin{array}{c}-0.1941^{* * *} \\
(0.0000)\end{array}$ & $\begin{array}{c}-0.6255^{* * *} \\
(0.0000)\end{array}$ & $\begin{array}{c}-1.6090^{* *} \\
(0.0312)\end{array}$ \\
\hline TANGIBLE $_{i t}$ & $\begin{array}{c}0.0498 \\
(0.6894)\end{array}$ & $\begin{array}{c}0.1394 \\
(0.3443)\end{array}$ & $\begin{array}{l}-0.2375 \\
(0.8559)\end{array}$ \\
\hline$F A G E_{i t}$ & $\begin{array}{c}-0.1266^{* *} \\
(0.0102)\end{array}$ & $\begin{array}{l}-0.1930 \\
(0.5076)\end{array}$ & $\begin{array}{c}1.8742 \\
(0.3469)\end{array}$ \\
\hline$L^{\prime} A B O U R_{i t}$ & $\begin{array}{c}0.0469^{* * *} \\
(0.0000)\end{array}$ & $\begin{array}{c}0.0600^{* * *} \\
(0.0000)\end{array}$ & $\begin{array}{l}-0.0134 \\
(0.8484)\end{array}$ \\
\hline CASHFLOW $_{i t}$ & $\begin{array}{c}0.0356^{* * *} \\
(0.0011)\end{array}$ & $\begin{array}{l}0.0310^{\star * *} \\
(0.0082)\end{array}$ & $\begin{array}{l}-0.0245 \\
(0.7587)\end{array}$ \\
\hline GROWTH $_{i(t-1)}$ & $\begin{array}{l}0.0821^{* *} \\
(0.0187)\end{array}$ & $\begin{array}{l}-0.0631 \\
(0.1054)\end{array}$ & $\begin{array}{l}-0.2324^{*} \\
(0.0616)\end{array}$ \\
\hline PRODUCTION $_{i t}$ & $\begin{array}{c}0.0210 \\
(0.3978)\end{array}$ & $\begin{array}{l}-0.0262 \\
(0.9180)\end{array}$ & $\begin{array}{c}11.4133 \\
(0.4334)\end{array}$ \\
\hline$C$ & $\begin{array}{c}2.3523^{* * *} \\
(0.0000)\end{array}$ & $\begin{array}{c}7.3077^{* * *} \\
(0.0000)\end{array}$ & \\
\hline$N$ & 709 & 709 & 582 \\
\hline$R^{2}$ & 0.1481 & 0.3992 & \\
\hline F statistics & 9.9098 & 2.6864 & \\
\hline P-value & 0.0000 & 0.0000 & \\
\hline Wald test (trị số $X^{2}$ ) & 126.9140 & 175.3472 & 30.30405 \\
\hline P-value & 0.0000 & 0.0000 & 0.0014 \\
\hline Hausman test (trị số $X^{2}$ ) & 156.7388 & & \\
\hline P-value & 0.0000 & & \\
\hline $\operatorname{AR}(1)$ & & & 0.0085 \\
\hline $\mathrm{AR}(2)$ & & & 0.5129 \\
\hline Sargan test & & & 0.6062 \\
\hline
\end{tabular}

Note: $\left({ }^{* * *}\right),\left({ }^{* *}\right)$ and $\left({ }^{*}\right)$ corresponds to $1 \%, 5 \%$ and $10 \%$ significance levels, respectively.

Source: Calculated out of the data set. 


\section{Conclusion and Recommendations}

\subsection{Conclusion}

This paper uses a data set of 130 Vietnamese listed agricultural firms during the period of 2008-2014 to detect the impact of bank credit and trade credit on the growth rate of sales of those firms. Using GMM estimation method, the paper reveals inverted-U shaped $(\cap)$ relations between bank credit and trade credit with the growth rate of sales of the firms. In concrete terms, if the ratio of bank credit to total assets is below 0.4334 , increased bank credit will trigger the growth rate of sales of the firms. The effect reverses if the ratio goes beyond that benchmark. The impact of trade credit on the growth rate of sales of the firms has the same pattern as that of bank credit, but with a benchmark ratio of 0.1928 .

The paper has also pointed out that labour productivity has a positive impact on the growth rate of sales of the firms. However, the equity and the growth rate of sales in the previous year seems to have adverse impacts on those of the present year, implying an unstable growth of the firms over time that may be a consequence of output market uncertainty and competition from rivals, among others. All the remaining variables do not have statistically significant coefficients.

\subsection{Recommendations}

Given the findings of the paper, recommendations are proposed so as to help firms maintain high rates of growth. In concrete, firms that have the ratio of bank credit to total assets exceeding the benchmark of approximately 0.4334 should consider restructuring debts to get them back to the benchmark. Firms should quickly repay due bank loans, especially those of high interest rates. In order to do so, firms should withdraw from those business fields that are not of profession, in addition to liquiditizing unused assets.

Firms that have the ratio of bank credit to total assets below 0.4334 may opt for expanding traditional market shares and entering new ones, especially those in foreign countries (if being financially and managerially competent enough). Firms should try to find ways to approach preferential (cheap) credit programs provided by the Government to create added value for products and upgrade technology so as to enhance competitiveness. Firms should also limit themselves in using short-term bank credit to finance investment since this will burden themselves with the pressure of promptly repaying loans since long-term investments always have uncertain outcomes.

As for trade credit, in order to grow as fast as possible firms should keep the ratio of trade credit to total assets up to approximately 0.1928 . Those firms that do not meet this requirement should adjust themselves. A solution for this is to carefully examine cash flows to repay due debts.
Firms should also quickly use borrowed capitals in the form of trade credit in production to recover it as fast as possible to avoid adverse impacts possibly emanating from changes in policy of trade credit providers. Firms that have a ratio of trade credit to total assets below 0.1928 should consider using more of this type of credit from reliable trade credit providers. In concrete, firms should sign trade credit contracts of buying inputs that are really needed for production and business. Such contracts will help firms be active in input supply, thereby ensuring the process of production to proceed as smoothly as possible in order to meet market demand and maintain high growth rate of sales.

\section{References}

Abor, J. Y., Agbloyor, E. K. \& Kuipo, R. (2004). Bank Finance and Export Activities of Small and Medium Enterprises. Review of Development Finance, 4, 97-103.

Aktas, N., de Bodt, E., Lobez, F. \& Stanik, J. (2012). The Information Content of Trade Credit. Journal of Banking \& Finance, 36, 1402-1413.

Angrist, J. D., \& Krueger, A. B. (2001). Instrumental Variables and the Search for Identification: From Supply and Demand to Natural Experiments. Journal of Economic Perspectives, 15(4), 69-85.

Atanasova, C. (2012). How Do Firms Choose between Intermediary and Supply Finance. Financial Management, 41(1), 207-228. https://doi.org/10.1111/j.1755-053X.2012.01183.x

Bertin, M. J., \& Warleta, M. M. (2012). Non-linear Relationship Between Growth Opportunities and Bank Debt: A Panel Data Analysis of Chilean Firms. Academia, Revista Latinoamericana de Administración, 50, 44-65.

Brennan, M., Maksimovic, V., \& Zechner, J. (1988). Vendor Financing. Journal of Finance, 43, 1127-1141.

Burkart, M., \& Ellingsen, T. (2004). In-Kind Finance: A Theory of Trade Credit. American Economic Review, 94(3), 569-590.

Cheng, N. S., \& Pike, R. (2003). The Trade Credit Decision: Evidence of UK Firms. Managerial and Decision Economics, 24, 419-438.

Chen, S. Y., \& Chen, L. J. (2011). Capital Structure Determinants: An Empirical Study in Taiwan. African Journal of Business Management, 5(27), 10974-10983.

Cragg, J. G. (1983). More Efficient Estimation in the Presence of Heteroscedasticity of Unknown Form. Econometrica, 51(3), 751-763.

Danielson, M. G., \& Scott, J. A. (2004). Bank Loan Availability and Trade Credit Demand. The Financial Review, 39, 579-600.

Ferris, J. S. (1981). A Transactions Theory of Trade Credit Use. Quarterly Journal of Economics, 96(2), 243-270.

Ferrando, A., \& Mulier, K. (2013). Do Firms Use the Trade Credit Channel to Manage Growth? Journal of Banking \& Finance, 37, 3035-3046. 
Fisman, R., \& Raturi M. (2004). Does Competition Encourage Credit Provision? Evidence from African Trade Credit Relationships, Review of Economics and Statistics, 86, 345-352.

Ge,Y., \& Qiu, J. (2007). Financial Development, Bank Discrimination and Trade Credit. Journal of Banking and Finance, 31, 513-530.

Gregory, B. T., Rutherford, M. W., Oswald, S., \& Gardiner, L. (2005). An Empirical Investigation of the Growth Cycle Theory of Small Firm Financing. Journal of Small Business Management, 43(4), 382-392.

Griliches, Z. (1983). Comparing Productivity Growth: An Exploration of French and U.S. Industrial and Firm Data. European Economic Review, 21, 45-81.

Ho, D. N. (2014). Model to Analyze the Relation between FDI and Economic Growth in Vietnam, Ph.D. Dissertation, National University of Economics, Hanoi, Vietnam.

Jiao, Y. (2010). Debt Issues and Capital Structure with Soft Information. Managerial Finance, 36(1), 4-21.

Kwon, O., Han, S. H., \& Lee, D. H. (2020). SME Profitability of Trade Credit during and after a Financial Crisis: Evidence from Korea. Journal of Asian Finance, Economics, and Business, 7(7), 35-47. https://doi.org/10.13106/jafeb.2020. vol7.no7.035

Mateut, S., Bougheas, S. \& Mizen, P. (2006). Trade Credit, Bank Lending and Monetary Policy Transmission. European Economic Review, 50, 603-629.

Minetti, R., \& Zhu, S. C. (2010). Credit Constraints and Firm Export: Microeconomic Evidence from Italy. Journal of International Economics, 83, 109-125.

Modigliani, F., \& Miller, M. H. (1958). The Cost of Capital, Corporate Finance and the Theory of Investment. American Economic Review, 48, 261-97.

Modigliani, F., \& Miller, M. H. (1963). Corporate Income Taxes and the Cost of Capital: A Correction. American Economic Review, 53, 433-43.

Nguyen, H. H., \& Lien, T. T. (2019). Factors influencing family business decision for borrowing credit from commercial banks: Evidence in Tra Vinh province, Viet Nam. Journal of Asian Finance, Economics and Business, 6(2), 119-122. https://doi. org/10.13106/jafeb.2019.vol6.no2.119

Nguyen, T. N. T. \& Trang T. Q. (2013). Relations between Leverage Use and Investment Decisions. Journal of Development and Integration, 9(19), 10-15. [in Vietnamese]

Nguyen, T. U. U., \& Thoa, T. T. K. (2015). Income Forecasting Ability of Operatioanl Cashflows: The Cases of Vietnamese Listed Firms. Journal of Development and Integration, 20(30), 34-42. [in Vietnames]

Nicholson, W., \& Snyder, C. (2008). Microeconomic Theory: Basic Principles and Extensions. Belmont, CA: Thomson Higher Education.
Nkurunziza, J. D. (2010). The Effect of Credit on Growth and Convergence of Firm Size in Kenyan Manufacturing. Journal of International Trade \& Economic Development, 19(3), 465- 494.

Le, K. N., \& Huynh, H. T. (2014). Profit and Investment Decisions under Market Uncertainty: An Empirical Study of Nonstate Firms in the Mekong River Delta. Review of Banking Technology, 104, 24-35. [in Vietnamese]

Le, A. H., \& Kim, T. (2020). The effects of economic freedom on firm investment in Vietnam. Journal of Asian Finance, Economics, and Business, 7(3), 9-15. https://doi.org/10.13106/ jafeb.2020.vol7.no3.9

Petersen, M. A., \& Rajan, R. G. (1997). Trade Credit: Theories and Evidence. Review of Financial Studies, 10(3), 661-691.

Psillaki, M., \& Eleftheriou, K. (2015). Trade Credit, Bank Credit, and Flight to Quality: Evidence from French SMEs. Journal of Small Business Management, 53(4), 1219-1240.

Rahaman, M. M. (2011). Access to Financing and Firm Growth. Journal Banking \& Finance, 35, 709-723.

Schwartz, R. (1974). An Economic Model of Trade Credit. Journal of Financial and Quantitative Analysis, 9(4), 643-657.

Schwartz, R., \& Whitcomb, D. (1979). The Trade Credit Decision. In: Handbook of Financial Economics (pp. 257-273). Amsterdam:. North-Holland Press.

Sola, C. M., Teruel, P. J. G., \& Solano, P. M. (2013). Trade Credit Policy and Firm Value. Accounting \& Finance, 53(3), 791-808.

Summers, B., \& Wilson, N. (2002). An Empirical Investigation of Trade Credit Demand. International Journal of the Economics of Business, 19, 257-270.

Tran L. T. H., \& Bay D. T. (2015). Ownership Structure and Devidend Policy of Listed Firms: Evidence from Vietnam. Journal of Development and Integration, 23(33), 72-78.

Tsuruta, D. (2015). Bank Loan Availability and Trade Credit for Small Businesses during the Financial Crisis. Quarterly Review of Economics and Finance, 55, 40-52.

Wilson, J. O. S., \& Morris, J. E. (2000). The Size and Growth of UK Manufacturing and Service Firms. The Service Industries Journal, 20(2), 25-38.

Wooldridge, J. M. (2001). Applications of Generalized Method of Moments Estimation. Journal of Economic Perspectives, 15(4), 87-100.

World Bank (2014). Fiancial Sector Assessment: Vietnam. Washington, DC: World Bank.

Yazdanfar, D., \& Ohman, P. (2015). The Impact of Credit Supply on Sales Growth: Swedish Evidence. International Journal of Managerial Finance, 11(3), 329 -340. 
